\title{
READING PROVERBS 7 IN THE CONTEXT OF FEMALE 'BLESSERS' AND SUGAR MAMAS IN SOUTH AFRICA
}

\author{
Madipoane Masenya (Ngwan'a Mphahlele) \\ University of South Africa
}

\begin{abstract}
The image of a woman who is portrayed negatively in Proverbs 1-9, that is, Woman Stranger, has been engaged variously by Hebrew Bible scholarship, especially by feminist biblical scholars. Some have argued that Woman Stranger is in fact one woman symbolic of a variety of traits. The trait that seems to feature glaringly in Proverbs 7 is that of a woman who exercises her sexual powers outside the boundaries of conventional heterosexual marriage. A new phenomenon occurs in present-day South Africa. Should the phenomenon be regarded as a sign of the deconstruction of patriarchy and its power to control female sexuality? It entails among others, the seduction of younger men, designated as Ben 10's, by older women (read: female 'blessers' and/or sugar mummies), something akin to what Woman Stranger is portrayed as doing to the young man in Proverbs 7. The main question addressed by this article is: If the preceding South African phenomenon is used as a hermeneutical lens to read the text of Proverbs 7, which light might be shed on such relationships especially in present day South Africa? To the honouree, Professor Hendrik Bosman, which teachings and commandments from the wisdom acquired and imparted through his teaching and parenting may he impart in the context discussed here?
\end{abstract}

Key Words: Woman Stranger; Prov. 7; Female Blesser; Sugar Mummy; Ben 10’s; Cross-generational; Sex

\section{Introduction}

The concepts of female 'blessers' and 'sugar mummies' engaged with in this article, form part and parcel of the broader discourse on cross-generational partnerships. In the preceding partnerships, cross-generational sex happens between an older woman and a younger man or between an older man and a younger woman. Although it may be argued that crossgenerational relationships are as old as humanity, literature from the fields of social sciences and health sciences among others, have focused mainly on relationships between older males/men and younger females/adolescents than on older females and younger men/boys. The preceding focus makes sense especially within varying patriarchal African contexts. Particularly in the era of the pandemic of HIV and AIDS in sub-Saharan Africa, many studies have revealed the danger posed by the relationships with sugar daddies to younger women/adolescent girls. The latter category is mostly reported as receiving the short end of the stick through STI/HIV infections and teenage pregnancies among others. ${ }^{1}$ To my knowledge, in the South African context, the only study that has intentionally addressed cross-generational relationships in the context of biblical hermeneutics was done by Gerald O. West and Beverley G. Haddad. ${ }^{2}$ However, like many other studies on cross-generational research, the focus of the preceding study is on the elderly male (sugar daddy [Boaz]) and the younger female [Ruth]. 
The text under investigation in this essay though, that is Proverbs 7, presents an unusual picture of a woman (Sugar Mummy or Female 'Blesser'(?) to use the South African jargon), who appears to delight in seducing younger men. As a way of situating the South African discourse on female 'blessers' and sugar mummies within the broader framework of cross-generational relationships, a brief overview will now be in order.

\section{Intimacy within Cross-generational Relationships?}

In literature, a sugar daddy (respectively a sugar mummy) is the name given to an older man (respectively older woman) who has sexual relationships with young girls (respectively young boys) in exchange for money and/or material goods. The latter may include drinks, gifts, clothes and favourable treatment. The preceding treatment may include various favours such as education, employment, tuition fees payment, financial support for subsistence costs and other kinds of support. The less powerful member of the relationship (cf. especially age and economic disparities) basically avails her/his body for sex in exchange for gifts. While many a young person, (cf. especially girl children in the context of the South African sugar daddies/male 'blessers' and sugar mummies/female blessers) get entangled in such relationships due to poverty (in some cases even being supported by parents), many of them are motivated by the materialistic context of globalization.

There is a considerable gap in knowledge regarding the different forms and conditions under which young people engage in sexual activities with older people globally, especially with regard to how they relate with sugar daddies and sugar mummies. The knowledge gap is caused partly by the fact that data on the practice of sugar daddies and sugar mummies is based on reports coming from the young people themselves. ${ }^{4}$ From literature though, it appears that the age gap between the sugar daddies and sugar mummies and their younger consorts varies from six years to more than twenty years (!) in certain cases. ${ }^{5}$

With the preceding brief overview on cross-generational relationships, we now turn to the phenomenon of female 'blessers' and 'sugar mummies' in the South African context.

\section{Patriarchy Problematised?}

A religious term has been hijacked terribly by its users within our daily jargon here in South Africa. The verb 'bless', one whose subject is usually believed to be the deity, has been hijacked by the so-called male and female 'blessers'. The 'blessers' become the subjects who by virtue of their higher socio-economic statuses are able to give (read: 'bless') the 'blessees' (read: the recipients of the 'blessers', gifts) material things. Given the notoriousness of sex work and the stigma on sex and sexuality not only within African settings, but also within many Christian African contexts, it boggles one's mind that a religious concept like 'bless' could be used to refer to payment for transacting with human bodies. According to Mercy Oduyoye though, among faith-based organisations it is not cross-generational sex which is abhorred and criminalized: it is sex outside of marriage. ${ }^{6}$

Who are the 'blessers'? ${ }^{7}$ Almost two years ago, when the phenomenon was 'started' in South Africa, only men featured in the media as 'blessers.' In recent months though, female persons have come out unashamedly and also declared themselves as 'blessers.' "Since the commencement of the Blesser \& Blessee trade, men have always been known as the Blessers but things are turning around the other way in Pretoria as women Blessers are emerging. The women blessers post vacancies on the internet, radio or posters. The female 
Masenya (Ngwan'a Mphahlele)

blessers then invite interested young and energetic men to apply for various positions. When an interview is scheduled, the men are seduced and become blessed after agreeing to be a Blessee." 8

The following snippets from some of the male 'blessers' and/or prospective ones are worth noting:

"Yes I usually go to them when I need money. I make an offer, and definitely will get someone who is ready to pay. It helps me. I don't even have to look for a job any longer."

Richie, a male 'Blessee' spoke to our reporter. ${ }^{9}$ When our team asked of the dangers, Richie said: "No money comes easily but with this there's no fears. Because all they need is sex. There are few instances they may not give as you proposed due to poor performance, but it's all good. As for HIV, I use condoms so I'm okay." ${ }^{\prime 0}$ (Italics: Author's.)

A prospective 'blessee' posted: "I am looking for a wealthy woman who can be my blesser and I will make sure she is always happy and satisfied" (Richards Bay, 083 9851991). ${ }^{11}$

From the preceding paragraphs it is clear that female 'blessers' (or traditional sugar mummies) are older and richer heterosexual women. They thus have the capacity to satisfy the many needs of young males. What they seem to lack though, is someone to satisfy their sex drives ${ }^{12}$ and perhaps also to massage their female egos. The words posted from a female 'blesser' throw light on the preceding status:

"Strict, yet subloving mistress seeking a sincere subslave who has a desire to serve a Superior Lady of Substance"13 (Kzn, SA).

The "Superior Lady of Substance" in the preceding quote, may not be compared with the 'eshet 'hayil', the woman of substance in Proverbs 31:10-31. There is nothing about wisdom that the sugar mummies (read: female 'blessers') claim because, "It has nothing to do with your religion and everything to do with what you're prepared to do for money, especially in black urban circles where 'blessers' are all the rage."14

In the light of the framework on cross-generational partnerships provided in the introduction to this essay, the concept of 'female blesser', will fall under the broader category of sugar mummies. The female 'blesser', just like her male peer, is much richer than the conventional sugar mummy. Sugar mummies may tend to establish more standing relationships with their younger consorts than would be the case with the 'blessers'. There exists an age and economic disparity between them and their consorts:

"I am just a boy seeking rich old women to love me (pmb)."

"Looking for rich sugar mom (Bronkhostspruit, SA)."

"Handsome boy looking for rich women Mummies in Bloem (37-55).,"15

Concerned about the havoc wreaked by the female 'blessers' within families, acting police chief Lieutenant-General Johannes Phahlane could thus warn:

I am not saying you must confess, I'm just saying it: Blessers and Ben 10's, while (your) children at home do not have anything to eat, you are busy 'blessing' someone. These are things which characterize our society today. I don't think all these things are taking us anywhere. ${ }^{16}$ 
As we unpack the preceding scenario and the kind of impacts that it may have in the (South) African contexts, could Hendrik Bosman the Sage, and the Proverbial sages offer any wise words?

\section{Any Word of Wisdom from Hendrik Bosman, the Sage?}

The context in which Woman Stranger (cf. Prov. 7) operated, called for the inculcation of wisdom values by the sages of the time. The sages dared not leave the unwise (male) youths without the words of wisdom and understanding (cf. Prov. 7:1-2) to avoid possible death-dealing situations. In the context where younger men have become easy prey to female 'blessers' and sugar mummies, the wise words from the sages like Hendrik Bosman, the honouree, have become urgent. Aware of the importance of the (African) context in the readers' encounter with the Hebrew Bible, elsewhere Bosman remarked: "...On the contrary, modern study of the Old Testament is in need of more readers that perceive and interpret Scripture as a response to African historicity!" ${ }^{17}$ Which teachings and commandments may Bosman impart in our day?

Having given the readers a glimpse about the broader and specific South African contexts of inter-generational relationships, we now turn to the book of Proverbs. In a context where female 'blessers'/sugar mummies and their Ben 10's move freely and comfortably without any warning from the sages, how may one read a text like Proverbs 7 ? Prov. 7 reflects the narrative of a woman who like a female 'blesser'/sugar mummy, dares to 'misbehave"18 by breaking conventional rules. Thus she acts deliberately against the patriarchal status quo.

\section{Navigating the Narrative of the Female Figure in Proverbs 7}

As one of the mechanisms to cope with the figure of Woman Stranger in Proverbs, Meike Heijerman ${ }^{19}$ suggests that female readers ignore Proverbs 7 because in her view the text was not meant for women. If we consider the predominantly male addressees of the Instruction of Proverbs 1-9, and the androcentric text of Proverbs, ${ }^{20}$ we may, in line with Heijermann's suggestion, end up ignoring the whole book. In this article, I will thus go against the grain of Heijerman's suggestion and read the character of Woman Stranger informed by the social location portrayed in the introduction to this essay: Could the South African female 'blessers'/sugar mummies and their clients find the content of Woman Stranger's narrative hitting closer to home?

Her narrative is inserted between exhortations signalling life (Prov. 7:2) and death (Prov. 7:27). Wisdom and insight, if befriended and embraced intimately (as wife [4:5-9; $7: 4-5])^{21}$ by the male youth, will necessarily secure him life. Right here at the beginning of the text that will present Woman Stranger's ${ }^{22}$ narrative, the sapiential notion of rewards and punishments is notable. Athalya Brenner has thus rightly observed: "The rewards of obedience, listening, acting decorously, seem in this optimistic worldview naturally to be expected." ${ }^{23}$ On the one hand, the youth's ability to heed and keep the words, commandments and teachings of the sage will reward him with life. The critical organs cited in the text are noteworthy. The youth should guard the teachings of the wise jealously, just as the eye guards and protects its own apple jealously. On the tablet of his heart (his mind/centre of selfhood, $)^{24}$ is to be written the words of the wise. He must be committed to doing what he is being taught by binding the teachings around his fingers. With the teachings on the tablet(s) of the youth(s)'s heart(s), ${ }^{25}$ the youth would not succumb to the ways of Woman Stranger $(7: 25)$. On the other hand, failure to keep the commandments and the words of the 
elder/parent/sage will lead to death as the youth would lack protection from the strange woman (7:4-5). In Prov. 7, the carrier of death is Woman Stranger, a woman who acts in a strange way. Experience embedded in history has revealed to the sage that the young men who have fallen prey to her seductions end up in Sheol:

"...for many are those she had laid low, and numerous are her victims.

Her house is the way to Sheol,

Going down to the chambers of death" (7:26-27: NRSV).

Unlike the South African Ben 10's who deliberately yield to the seductions of the female 'blessers'/sugar mummies, the male youth in Proverbs is assured of death should he revel in senselessness and folly by succumbing to Woman Stranger's seductions. Some of the salient features expected from the 'eshet hayil in the South African context will be used here below, as pointers through which the activities of Woman Stranger are interrogated.

\section{Married Heterosexually}

Woman Stranger, unlike many a South African female 'blesser' and sugar mummy, is a married woman (7:19-20). Unlike the household managers of Yehud (cf. the 'eshet hayil in Prov. 31:10-31), Woman Stranger does not seem to feel comfortable in the private sphere of the home, the one which her society expects that she would manage with efficiency, "...her feet ${ }^{26}$ do not stay at home...". It is interesting to note that the home is referred to as 'her house' betah (ביתח, cf. 7:8, 27) (in her house) (7:11). The bed on the property is also hers (v. 17). ${ }^{27}$ In a patriarchal context, the house and the wife belong to the man, the wife's ba'al (master). However, the (illegitimate) power of Woman Stranger seems to be acknowledged by the sage, the power not only to own a house, but also to employ the house to use male sexuality for her pleasure, for as long as the legitimate household head is absent from the house. Although Wisdom, and Wisdom personified as a woman in Proverbs does go to the public space, as in the case of the 'eshet hayil, she does that, for the good of the whole family, including the good of her husband (Prov. 31:16:ff). In the case of Woman Stranger though, outside ventures are motivated by her power of seduction - lying in wait to catch her male prey. The main goal of her actions are self-serving, geared at the satisfaction of her enduring sexual desire, "...now in the street, now in the squares, at every corner she lies in wait." She seizes him and kisses him, and with impudent face she says to him; "I had to offer sacrifices and today I have paid my vows; so now I have come out to meet you, to seek you eagerly, and I have found you.'(Prov. 7:12, 14). Could it be that even in this scenario, as in the case of the verb 'bless' above, religious jargon has been hijacked into unlikely spaces? Van Leeuwen sees the irony here, that Woman Stranger's payment of her 'vows' and 'sacrifices' meant that she was then free, it would appear, to have a feast and a liaison. ${ }^{28}$

At least from her portrayal in Proverbs 7, Woman Stranger has no children, something that may not come as a surprise because woman as mother, especially in the Instruction genre of Proverbs, does not feature prominently. ${ }^{29}$ At the same time, a woman who refuses to be domesticated such as Woman Stranger could not have passed the test of being a good mother. How could a woman who dares share the marital bed with strangers be trusted to produce holy seed? If she had children, which model would she have provided for them? Would the sages have encouraged the young men not to neglect the torah taught by such a mother (Prov. 1:8-9; 6:20).

What now of the husband of Woman Stranger? Just like the husband of the 'eshet hayil in Prov. 31:10-31, Woman Stranger's husband, like many black South African men, es- 
pecially during the apartheid era, is an absent family head. Perhaps his absence was a sign of his commitment towards the provision of his apparently rich household. Could he have been one of the businessmen of his time? Whatever his career was, it gave him the freedom not to be tied to his house. He was able to go to the (male) public sphere. His absence (unlike Woman Stranger's) from what is supposed to be his house did not seem to bother the sage in Proverbs 7. Little did Woman Stranger's husband know that his absence would create fertile ground for chaos (and death) not only on his marriage, but on the lives of many young men who would become victims of the seductions of his apparently 'untamed' wife, a woman who according to Van Leeuwen is "...sexually and spiritually out of bounds." 30

May Woman Stranger's husband have contributed to the behaviour of his wife? Who is supposed to take care of his wife's sexual needs during his long periods of absence? Or do waiting wives always have the capacity to navigate sexual starvation with ease? Could it be that even apart from his long periods of absence, during his presence at home, he was not able to satisfy the sexual needs of his wife? The words of Alexander Abasili come to mind here:

If a young man neglects the sexual satisfaction provided by his wife, says Pr. 5:16, then the wife may seek sexual satisfaction elsewhere, outside the marriage. In this way, the author of Proverbs, without justifying the adulterous act of a neglected woman, underlines one of the reasons that can make a woman stray from her marital vow: lack of sexual satisfaction and attention from the husband. ${ }^{31}$

In an androcentric canon where the beauty and sexuality of a woman are hardly celebrated, the answers to the preceding questions remain pure speculations. Woman Stranger is a married woman who acts like a woman possessed by no man. She seems to be persuaded that her body and her sexuality belong first and foremost to her. What is not certain though is whether what she is portrayed as doing excellently, boldly and with ease in Prov. 7, can be done even when her ba'al is present. The question we now turn to is: could we safely conclude that Woman Stranger had control over her sexuality?

\section{Who owns Woman Stranger's Body?}

The portrait which the sage presents about Woman Stranger is that of anything but a married woman, one who unashamedly and deliberately transgresses the sexual boundaries within which a married couple was expected to operate. Heijermann reasons that Woman Stranger lives outside the confined roles of society and is thus able to say and do what is socially not acceptable, thus revealing her unanticipated power. ${ }^{32}$ The Woman of Worth is presented as managing the affairs of a complex household with efficiency. The asexual nature of her portrait may give readers an impression that hers is an exaggerated picture. However, it also bears evidence that in the Hebrew Bible (including in the book of Proverbs), female sexuality is not celebrated in its own right, especially from the perspective of female pleasure. ${ }^{33}$ Sexual moves by women, especially foreign women, are usually problematized. It is thus possible that the questionable sexual moves of Woman Stranger may be a pointer to her foreign origins. ${ }^{34}$

She appears to have taken charge over her sexuality because she poses as a man. Unlike the 'eshet hayil who is found (see the root מצא) by a man, (cf. Prov. 31:10 and Prov. 18:22), Woman Stranger goes out and seeks a young man until she has found him (מצא; Prov. 7:15). Yoder is on target when she reasons that, "Everything points to the woman's relentless pursuit of the youth who, in a moment of folly, all too quickly becomes her victim. Indeed, 
her invitation reduces him instantly to an animal rushing heedlessly to the slaughter" (7:2223). ${ }^{35}$ The object of her search is not a legitimate partner, but just like in the case of the South African female 'blesser'/sugar mummy, the search object is a young man who can please her even if for a one-night stand:

"Come, let us take our fill of love until morning;

Let us delight ourselves with love.”(Prov. 7:18).

A reversal of gender roles happens here. The active-male-seeker-husband is replaced by the active-female-seeker wife whose prey is not elderly men, but younger men! The latter are portrayed as real helpless victims who have fallen prey to a highly sexualized woman. The prostitute attire $^{36}$ that she wears makes her potential male victims yield easily to her seductions, for who, in their right minds, would dare tamper with the property of a married man? Elsewhere the sage had sternly warned:

For jealousy arouses a husband's fury

And he shows no restraint when he takes revenge.

He will accept no compensation,

And refuses a bribe no matter how great (Prov. 6:34-35).

Read through modern eyes, Woman Stranger's imposition on the young man through seizing and kissing, borders, at least at face value, on sexual harassment. May this be understood by others as rape? Woman Stranger's courage to invite the young man/men to her house/body/bed in the absence of her ba'al points to the share of the ba'al's extant power over her sexuality. Although it may not be disputed that she has control over her own sexuality, the latter seems to happen only when the legitimate owner of her body is absent. In the context of such an unstoppable, highly sexualized adulterous woman, young men are encouraged to make intimacy with wisdom in order to avoid death (7:4-5,) for as Streete has argued, "Sex with the Strange Woman is intimacy that kills." 37

\section{An Innocent Passive Victim or a Consenting Silent Participant?}

Just like the portrait of Woman Stranger, one that not only appears to be exaggerated, but also depicts something of the reversal of normative gender roles in a patriarchal context, the portrait of the male youth depicted by the sage in Proverbs 7, appears to be unusual. Unlike the South African Ben 10's who are portrayed as actively involved in the search for female 'blessers' and sugar mummies, the male youth of Proverbs 7 is portrayed as a passive person, an object to be found by a relatively older woman. Concerning the latter though, we may not be certain about the age gap between the youth and Woman Stranger. However, in the light of the lead she takes, the seductive speech she employs, the cheating tactics among others, she does not appear to be young. The youth's glaring passivity and loud silence serve to help readers anticipate his fate in the end (7:21-23). After the eager search by the woman, the youth is acted upon: found, seized, kissed, promised a perfumed bed and "...a fill of love until morning" (7:18), persuaded and compelled with seductive speech and smooth talk. Are men depicted as being unmanned by (strange) women or is the portrait a deliberate one to show that not all the sons (addressees of the proverbial sages) did heed their words? The youth and his reaction to the wiles of a strange woman depicts him as a real fool. Pertinent questions are to be asked though: Is the youth really innocent? Could his passivity and silence be a revelation of his deep anxiety and yearning to fulfill his youthful lusts? Could it be that his male ego was massaged by being eagerly sought and lusted after by the wife of a rich man? If the young man was really committed to making wisdom 
(בכפה) his sister and insight (בינה) his intimate friend (7:4), why did he not run away from the woman? Why is he in the neighbourhood of Woman Stranger's house anyway, “...taking the road to her house"(NRSV) ודרד ביתח יצע? Why did he choose to go to a potentially dangerous place especially during that time of the day? "...in the twilight, in the evening, at the time of night and darkness." (RSV) ${ }^{39}$ Says Kidner, "He wanders into temptation, where place (7:8) and time (7:9) can join forces against him; and if he is aimless, his temptress is not." 40

The words of Carole Fontaine come to mind here: "Any wrongdoing that may result from an encounter with her is attributed to her powers of persuasion and seductive bearing; the man's complicity and cooperation - other than stupidity - go unnoted."41 The perpetrator of chaos, folly and death, so argues the sage, is female; the male's intentional yielding to her wiles is not foregrounded though his folly was predicted and expected.

\section{Conclusion: A Strange Version of Normative Womanhood?}

The dynamics revealed by Woman Stranger's actions and the female 'blessers' above, reveal something of the complexity of traditional gender roles both in Yehud and in present-day South Africa. As they were not neatly demarcated, they gave the sages a hard time by having to add to their wisdom syllabus, the subject on strange women. Women in the preceding cross-generational relationships choose/chose deliberately to transgress the conventional boundaries by doing the following, among others:

- Firstly, male persons as husbands feature less (cf. Woman Stranger) or not at all in their lives (cf. female 'blessers' and sugar mummies). Women thus succeed in mocking heteropatriarchy and its capacity to tame (married) women's lives. The women destabilise the integrity of the traditional patriarchal heterosexual family by creating unconventional families (e.g. female-headed ones and covert polyandries in the case of the South African female 'blessers' and sugar mummies).

- Secondly, whether they are married or not, the women are fully in charge of their sexuality and celebrate it unashamedly. For married women, the issue of a politically correct seed becomes problematized as mothers are usually the ones who know the real fathers of their children. Herein lurks the danger though, since research has revealed that the younger girls attached to sugar daddies are the main victims of STI/HIV transmissions, while they also choose to court the sugar daddies simultaneously with their peers. The younger men, who may then be infected by their female peers, are likely to infect the female blessers and the sugar mummies. At the same time, on account of the age and economic disparities between themselves and the younger consorts the female 'blessers' and the sugar mummies are likely to challenge the use of condoms. Such an unfortunate vicious cycle will pose a serious threat in our fight against the pandemic of HIV and AIDS.

- Thirdly, the women are relatively richer compared to their consorts. In the South African context for example, the women's higher socio-economic class is the driving force towards the birthing of the category of female 'blessers'. The portrayal of a husband with lots of money in Prov. 7 reveals, albeit overtly, that his wife would also have money. Her bed's expensive furnishings and perfumes promised as gifts to the young man, point to Woman Stranger's higher socio-economic status.

- Fourthly, the women's power of seduction not only unman men, they also cause chaos to the patriarchal order. In the process, they also make a mockery of the gifts of love and sex. What the sage has declared elsewhere to be too wonderful and hard to 
understand, ${ }^{42}$ has been frustrated here. Sex no longer becomes an expression of love between two consenting adults within the confines of marriage, sex can happen in a loveless, cold, yet highly commercialised atmosphere. Oduyoye is thus adamant that in such cases, sex can hardly be regarded as consensual "... as it does not derive from love, desire or fascination on the part of the younger person: it is a demonstration of power." 43

- Fifthly, regarding the young men involved, the elitist context provided by Proverbs allows us to speculate that the addressees were not poor. Van Leeuwen can thus say that "the wisdom transferred from parent to (male) child, teacher to pupil, prepares him for a successful conventional life within his (mostly upper class) circle." 44 The young man in Proverbs 7, unlike the South African Ben 10's, was not seduced by the material things that Woman Stranger promised. Whatever material things Woman Stranger was capable of dispensing as temporary gifts, were geared at the illegitimate gift of her sexuality. Young men who chose intimacy with her, would end up in social or even physical death.

What about the South African Ben 10's? Are all the younger men involved really poor or are most of them basically overwhelmed by the desire for materials things? Could their family backgrounds be playing an important role in their activities? Even if they were really poor, in the commitment of all South Africans to build stronger and healthier families, is that the way to go? What kind of masculinity is created and nurtured by their behaviour? Even more importantly the question put to Professor Hendrik Bosman is: which wise teachings and commandments acquired and imparted through the years in your teaching and parenting may you speak to the critical scenario discussed in this article?

The words of Van Leeuwen come to mind here:

At stake in the symbolism of women, ways, and houses is the very structure of the universe itself, a world where life is a journey (way) motivated by love for either Wisdom or Folly, whose end is life or death. The conditions for life in this world are thus: freedom with form, love within limits, and life within law. To try to live outside the (moral) order of existence is to enter the realm of death. ${ }^{45}$

\section{BIBLIOGRAPHY}

Abasili, Alexander I. The Understanding of Adultery in the Hebrew Bible: A Critical Survey. UK: Xlibris, 2016.

Bibleworks- [c:|program files(X86)\bibleworks8\initlbw800.swc]; Proverbs 7, The False Attractions of Adultery.

Brenner, Athalya. The Israelite Woman: Social Role and Literary Type in Biblical Narrative. Sheffield: JSOT, 1985.

Brenner, Athalya. "Proverbs." Pages163-174 in Global Bible Commentary. Edited by Daniel Patte. Nashville: Abingdon, 2004.

Musa W. Dube. "Talitha Cum! Calling the Girl Child and Women to Life in the HIV/AIDS and Globalization Era," Pages71-93 in African Women, HIV/AIDS and Faith Communities. Edited Isabel A. Phiri, Beverley Haddad, Madipoane Masenya (ngwana' Mphahlele). Pietermaritzburg: Cluster, 2003.

Habtu, Tewoldemedhin. "Proverbs." Pages 571-604 in Africa Bible Commentary. Edited by Tokunbo Adeyomo. Nairobi: WorldAlive Publishers, 2006. 
http://scriptura.journals.ac.za

Reading Prov. 7 in the Context of Female 'Blessers' and Sugar Mamas in South Africa

Heijerman, Meike. "Who Would Blame Her? The "Strange" Woman of Proverbs 7." Pages 100-109 in A Feminist Companion to Wisdom Literature. Edited by Athalya Brenner Sheffield: Sheffield Academic Press, 1995.

Bird, Phyllis A. "Images of Woman in the Book of Proverbs." Pages 41-60 in Religion and Sexism: Images of Woman in the Jewish and Christian Traditions. Edited by Rosemary R. Ruether. New York: Simon and Schuster, 1974.

Fontaine, Carole 1992. "Proverbs". Pages 145-152 in The Women's Bible Commentary. Edited by Carol A. Newsom and Sharon H. Ringe. Louisville, KY:

Westminster/John Knox, 1992.

https://www.hepays.com/dating/sugar-mamma-rich-older-woman-Pretoria-MamelodiSouth Africa, accessed on 9 June 2017.

http://www.enca.com/south-africa/sa-police-chief-speaks-against-blessers-and-ben-10s, accessed on $10^{\text {th }}$ June 2017.

Kuate-Defo, Barthelemy. "Young People's Relationships with Sugar Daddies and Sugar Mummies: What do We know and what We need to know," African Journal of Reproductive Health 8(2):13, Aug. 2004:13-37;

http://www.bioline.org.br/request?rh04023(1 of 29)1/20/2005; 9:47:43).

Kidner, Derek. Proverbs. King James Version. Leicestor: Inter-Varsity, 1988.

Kittel, Rudolph (ed.). Biblia Hebraica Stuttgartensia. Stuttgart: Deutsche Bibelstiftung, 1977.

Luke, Nancy and Kurtz, Kathleen M. Cross-generational and Transactional Sexual Relations in Sub-Saharan Africa: Prevalence of Behaviour and Implications for Negotiating Safer Sexual Practices. Washington, D.C.: AidsMark c/o, Population Services International, 2002.

Luke, Nancy. "Confronting the 'Sugar Daddy' Stereotype: Age and Economic Asymmetries and Risky Sexual Behaviour in Urban Kenya," International Family Planning Perspectives 31(1) 2005:6-14.

Masenya Madipoane J. In the School of Wisdom: An Interpretation of Some Old Testament Proverbs in a Northern Sotho Context. Masters Dissertation, Pretoria: University of South Africa, 1989.

Meekers, Dominiques and Calves, Anne-Emmanuele, “'Main’ Girlfriends, Girlfriends, Marriage, and Money: The Social Context of HIV Risk Behaviour in Sub-Saharan Africa," Health Transition Review Supplement to Volume 7 (1997):361-375.

MoveMaghttp://movemag.co.za/blesser-is-the-new-buzzword-heres-what-it-means/, accessed on $11^{\text {th }}$ June 2017.

New Revised Standard Version. Nashville: World Publishing.

Sephodi, Malebo 2017. Miss Behave, Blackbird Books: Auckland Park.

Streete, Gail C 1997. The Strange Woman: Power and Sex in the Bible. Louisville:

Kentucky: Westminster John Knox, 1997.

Oduyoye, Mercy A. "Cross-generation Sex and its Impact on the Spread of HIV." Pages 301-312 in People of Faith and the Challenge of HIV/AIDS. Edited by Mercy A. Oduyoye and Elisabeth Amoah. Ibadan: Sefer, 2004.

West, Gerald O. and Haddad, Beverley G., "Boaz as 'Sugar Daddy': Re-Reading Ruth in the Context of HIV”, JTSA 155 July Special Issue (2016):137-15. 
Van Leeuwen, Raymond C. "The Book of Proverbs.” Pages 19-264 in The New Interpreter's Bible: A Commentary in Twelve Volume; Introduction to Wisdom Literature. Edited by Leander Keck. Nashville: Abingdon: Nashville, 1997.

Yoder, Christine R. "Proverbs." Pages 241-242 in Women's Bible Commentary, TwentiethAnniversary Edition, Revised and Updated. Edited by Carol A. Newsom, Sharon H. Ringe and Jacqueline E. Lapsley. Louisville, KY: Westminster John Knox, 2012.

\section{Endnotes}

1 Dominique Meekers and Anne-Emmanuele Calves, "Main' girlfriends, girlfriends, marriage, and money: the social context of HIV risk behaviour in Sub-Saharan Africa," Health Transition Review Supplement to Volume 7(1997):361-375; Gerald O. West and Beverley G. Haddad, "Boaz as 'sugar daddy': Re-Reading Ruth in the Context of HIV", JTSA 155 July Special Issue (2016):137-156; Nancy Luke and Kathleen M. Kurtz. Cross-generational and Transactional Sexual Relations in Sub-Saharan Africa: Prevalence of Behaviour and Implications for Negotiating Safer Sexual Practices (Washington, D.C.: AidsMark c/o, Population Services International, 2002).

2 West and Haddad, "Boaz as "Sugar Daddy", 137-156. (Cf. also Dube and Oduyoye among others, in the context of globalization and the broader African context respectively). Musa W. Dube, "Talitha Cum! Calling the Girl Child and Women to Life in the HIV/AIDS and Globalization Era," in African Women, HIV/AIDS and Faith Communities, eds. Isabel A. Phiri, Beverley Haddad, Madipoane Masenya (ngwana' Mphahlele), (Pietermaritzburg: Cluster 2003), 71-93; Mercy A. Oduyoye, "Cross-generation sex and its impact on the spread of HIV" in People of Faith and the Challenge of HIV/AIDS, eds. Mercy A. Oduyoye and Elisabeth Amoah, (Ibadan: Sefer, 2004), 301-312.

3 Barthelemy Kuate-Defo, "Young People's Relationships with Sugar Daddies and Sugar Mummies: What do we know and what we need to know?" African Journal of Reproductive Health 8(2):13, Aug. 2004:13-37 ; http://www.bioline.org.br/request?rh04023(1 of 29)1/20/2005; 9:47:43); Nancy Luke, "Confronting the 'sugar daddy' Stereotype: Age and Economic Asymmetries and risky sexual behaviour in Urban Kenya," International Family Planning Perspectives 31(1)2005:6-14; West and Haddad, "Boaz as 'sugar daddy', 137156; Dominique Meekers and Anne-Emmanuele Calves, “"Main’ girlfriends, girlfriends, marriage, and money...", 361-375.

4 Kuate-Defo, "Young People's Relationships with Sugar Daddies and Sugar Mummies," 16; (See also the South African examples provided in this essay).

$5 \quad$ Kuate-Defo, "Young People's Relationships with sugar daddies and sugar mummies,"16; Nancy Luke and Kathleen M. Kurtz. Cross-generational and Transactional Sexual Relations in Sub-Saharan Africa, 2002.

6 Oduyoye, "Cross-generation sex and its impact on the spread of HIV," 301-312.

7 A blesser is a sugar daddy who is very rich. Benefits from the blesser could include overseas holidays, a car and for a level one blesser, even an apartment! 'Blesser' is the new buzzword whose origins can be traced as follows: jobless young women posted about their exotic lifestyles claiming that they were 'blessed.' Their fellow social media users asked who their 'blessers' were. The words 'bless' and 'blesser' then started to circulate and are now commonly used. The 'blessers' are mostly based in the northern suburbs of Johannesburg. On the one hand, a Ben 10, named after the children's cartoon, is used colloquially in South Africa to refer to a young man dating or having sex with an older woman. Blessers on the other hand, are sugar daddies. http://movemag.co.za/blesser-is-the-new-buzzword-heres-what-it-means/. Accessed on 11 June 2017

8 https://www.hepays.com/dating/sugar-mamma-rich-older-woman-Pretoria-Mamelodi-South Africa, $2017,2$. Accessed on 9 June 2017.

9 https://www.hepays.com/dating/sugar-mamma-rich-older-woman-Pretoria-Mamelodi-South Africa, $2017,2$. Accessed on 9 June 2017.

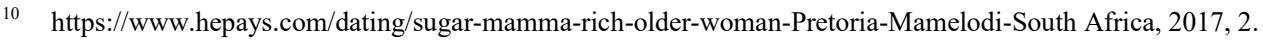
Accessed on 9 June 2017.

11 https:/www.hepays.com/dating/sugar-mamma-rich-older-woman-Pretoria-Mamelodi-South Africa, $2017,2$. Accessed on 9 June 2017.

12 One male Blessee commented, "Because all what they need is sex." (See endnote 10.) 
$13 \mathrm{https} / /$ www.hepays.com/dating/sugar-mamma-rich-older-woman-Pretoria-Mamelodi-South Africa, $2017,2$. Accessed on 9 June 2017.

14 http://movemag.co.za/blesser-is-the-new-buzzword-heres-what-it-means/ Accessed on 11 June 2017.

15 https://www.hepays.com/dating/sugar-mamma-rich-older-woman-Pretoria-Mamelodi-South Africa. Accessed on 9 June 2017.

$16 \mathrm{http} / /$ www.enca.com/south-africa/sa-police-chief-speaks-against-blessers-and-ben-10s. Accessed on 10 June 2017.

17 Hendrik Bosman, "African and Old Testament Concepts of Time and History," in Interpreting the Old Testament in Africa: Papers from the International Symposium on Africa and the Old Testament in Nairobi, October 1999. Eds. Mary Getui, Knut Holter and Victor Zinkuratire (New York: Peter Lang, 2001), $110[101$ $112]$.

18 In her book titled, Miss Behave, Malebo Sephodi argues that the concept of 'misbehaving' does not always entail bad behaviour. Its meaning depends on the ideological underpinnings of its user. Malebo Sephodi, Miss Behave (Blackbird Books: Auckland Park, 2016), 28-29.

19 Heijerman, Meike, "Who Would Blame Her? The 'Strange' Woman of Proverbs 7" in A Feminist Companion to Wisdom Literature, ed. Athalya Brenner (FCB, 9; Sheffield: Sheffield Academic Press, 1995), 105[100109].

20 "That the producers as well as the consumers of this seemingly oral - but for us readers literary - training were males seems to be borne out by the texts themselves, as well as by the preoccupation with female figures, personifications and metaphors." Athalya Brenner, 'Proverbs' in Global Bible Commentary, ed. Daniel Patte (Nashville: Abingdon, 2004), 163-174 (167). However women are portrayed by the proverbial sages, they appear to have been a force to reckon with in the context of the production of these texts.

21 Gaile C. Streete, The Strange Woman: Power and Sex in the Bible (Louisville: Kentucky: Westminster John Know Press 1997), 106; Christine R. Yoder, "Proverbs" in Women's Bible Commentary; TwentiethAnniversary Edition, Revised and Updated, eds. Carol A. Newsom, Sharon H. Ringe and Jacqueline E. Lapsley (Louisville, KY: Westminster John Know Press, 2012), 236 [232-242]; Athalya Brenner, The Israelite Woman: Social Role and Literary Type in Biblical Narrative (Sheffield; JSOT, 1985).

22 The woman is introduced as 'other' without any specific reason. In one breath, argues Yoder, the father calls her an 'outsider' (zara) and a 'stranger' or foreigner (nokriyya, 2:16). She represents all sorts of Strange women who will affect the youth's wellbeing negatively: she is another man's wife $(6: 24-35 ; 7: 19-20)$; one who breaks her covenant and devalues religious obligations (7:14-15), a woman dressed like a prostitute (7:10)... Yoder, "Proverbs", 235.

23 Athalya Brenner, "Proverbs" in Global Bible Commentary, ed. Daniel Patte. (Nashville: Abingdon, 2004), 167[163-174]; Madipoane J. Masenya, In the School of Wisdom: An Interpretation of Some Old Testament Proverbs in a Northern Sotho Context, Masters Dissertation (University of South Africa: Pretoria, 1989 ), 86. According to Streete, "Those who love her (Wisdom) are successful and happy $(8: 21,32)$; those who reject her are in love with death" (8:36), Streete, "The Strange Woman," 111.

24 Raymond C. Van Leeuwen, "The Book of Proverbs" in The New Interpreter's Bible: A Commentary in Twelve Volume; Introduction to Wisdom Literature, ed. Leander Keck (Abingdon: Nashville, 1997), 19-264 (86).

25 See the use of the plural form in verse 7 and in verses 24-25.

26 The term for legs (Heb. raglayim) anticipates the motive behind her roaming because the word, 'legs' is a common euphemism for private parts (Judges 3:24; $11 \mathrm{Ki1}$. 8:27; Isa. 7:20); the house, the sexual place proper for a married woman (Van Leeuven, 'Proverbs', 85).

27 If the views of authors such as Brenner, Fontaine and Streete among others, that on account of the posture adopted by the narrator of this story (cf. the position of looking through a lattice at the window of a house as a female posture in those days), we would note that the female narrator also refers to Woman Stranger's house as hers.

28 Van Leeuwen, "Proverbs", 85.

29 Phyllis A. Bird, "Images of woman in the book of Proverbs", in Religion and Sexism: Images of Woman in the Jewish and Christian Traditions, ed. Rosemary R. Ruether (New York: Simon and Schuster, 1974), 41-60.

30 Van Leeuwen, "The Book of Proverbs", 84.

31 Alexander Abasili, The Understanding of Adultery in the Hebrew Bible: A Critical Survey (UK: Xlibris, 2016), 313. 
32 Heijerman, "Who would blame her?...",108.

33 It is celebrated basically in its reproductive capacities, especially the birthing of male babies.

34 See also Athalya Brenner, The Israelite Woman: Social Role and Literary Type in Biblical Narrative (Sheffield; JSOT, 1985), 121-122.

35 Yoder, "Proverbs", 233.

36 Although she is not presented as a prostitute, Woman Stranger's deliberate garb will make those who see her identify her as one. Her attire already reveals that she is a married woman who crosses sexual boundaries for as Brenner would argue, a woman who betrays her husband is referred to as a prostitute as she has 'turned away' from her lawful spouse. The Israelite Woman: Social role and Literary Type in Biblical Narrative (Sheffield: JSOT, 1985), 79.

37 Streete, "The Strange Woman," 109.

38 Passing through the street near her corner, and he went the way to her house (KJV) (8) NAS: Passing through the street near her corner, And he takes the way to her house (8) RSV: passing along the street near her corner, taking the road to her house (8).

39 KJV: Evening, in the black and dark night. NAS in the twilight, in the evening, in the middle of the night and in the darkness. RSV: in the twilight, in the evening, at the time of night and darkness (Bibleworks[c: $\mid$ program files(X86) \bibleworks8 4 init $\backslash$ bw800.swc]; Proverbs 7 The False Attractions of Adultery.

40 Derek Kidner, Proverbs. Leicestor: Inter-Varsity Press, 1988, as quoted by Tewoldemedhin Habtu, "Proverbs" in Africa Bible Commentary, ed. Tokunbo Adeyomo (Nairobi: WorldAlive Publishers, 2006), 757.

41 Carole Fontaine, "Proverbs" in The Women's Bible Commentary. Eds. Carol A. Newsom, Sharon H. Ringe (Louisville, KY: Westminster/ John Know Press, 1992), 145-152 (148).

42 "Three things are too wonderful for me; four I do not understand ... and the way of a man with a girl" (Prov. 30:18-19, NRSV).

43 Oduyoye, "Cross-generation Sex and its Impact on the Spread of HIV," 303.

44 Van Leeuwen, "The Book of Proverbs", 84.

45 Van Leeuwen, "The Book of Proverbs", 86. 